\section{Use of LIDAR-based digital terrain model and single tree segmentation data for optimal forest skid trail network}

\author{
Krzysztof Sterenczak $^{(1)}$, Tadeusz Moskalik ${ }^{(2)}$
}

The implementation of effective and sustainable logging operations requires an optimal forest accessibility through appropriately planned roads and optimized skid trail network. Skid trails delineation depends on the logging method used, the existing road network, the stand development, and the terrain conditions. This paper explores the possibility of using the Airborne Laser Scanner (ALS) technology and Geographic Information System (GIS) to determine the optimal or near-optimal locations and routes of forest skid trails in a Scots pine stand in central Poland. A suitable algorithm was developed for the optimization of the skid trail network. The model designs the best route taking advantage of the existing stand gaps in order to minimize the number of trees to be felled for the skid trail construction. Spatial distribution of trees in the stand was obtained with the use of a segmentation procedure. Results showed a reduction after optimization of $2 \%$ in the overall length of skid trails for traditional harvesting methods (skid trails at a minimum distance of $40 \mathrm{~m}$ ). For fully-mechanized harvesting methods, the skid trail network was denser (minimum distance: $20 \mathrm{~m}$ ) and the original total skid length was reduced by only $0.06 \%$. The advantages of the adopted procedure for optimizing the delineation and construction of skid trail networks are discussed.

Keywords: Logging, Airborne Laser Scanner, Single Tree Detection, Digital Terrain Model, Optimal Forest Skid Trail Network

\section{Introduction}

The efficiency of logging operations in forest stands are largely dependent on the availability of an adequate access through a transportation network, in terms of roads adjacent to wood storage areas and operational trails allowing machines to easily move inside the stand.

Secondary forest roads, known as strip roads or skid trails, are constructed infrastructure occasionally used to execute the tasks of a management plan. They are primarily intended for skidding or forwarding operations (Pentek et al. 2008). The density of skid trails and their arrangement depend on many factors (Nevečerel et al. 2007): timber harvesting method and system, configu-

ration, terrain rockiness, tree density and dimensions, and the position of the main forest truck road, to which the timber is extracted.

Optimizing the system of roads and trails is a complex process. Optimal trail spacing can be influenced by many factors, such as logging method, price of products, taxation policies, landing costs, overhead costs, equipment opportunity costs, road width and size of landing, skidding pattern, profit of logging contractor, slope, topography and soil disturbance (Heinimann 1997).

The first forest road-spacing scheme, along with the theoretical mean skidding distance, was presented by Matthews (1942). Models of optimal road networks for forest areas have been published many-fold in the litera-

$\square$ (1) Forest Research Institute, Department of Information Technology and Modelling, Braci Lesnej 3, 05-090 Raszyn (Poland); (2) Warsaw University of Life Sciences - SGGW, Department of Forest Utilization, Faculty of Forestry, Nowoursynowska 159, 02-776 Warszawa (Poland)

@ Tadeusz Moskalik (tadeusz.moskalik@wl.sggw.pl)

Received: May 20, 2014 - Accepted: Aug 22, 2014

Citation: Sterenczak K, Moskalik T, 2014. Use of LIDAR-based digital terrain model and single tree segmentation data for optimal forest skid trail network. iForest 8: 661-667 [online 2014-12-22] URL: http://www.sisef.it/iforest/contents/?id=ifor1355-007

Communicated by: Enrico Marchi ture. Some papers proposed an evaluation of alternative trail routes based on economic considerations only (Kobayashi 1984, Newnham 1995, Jourgholami et al. 2013), while others were based on specific information obtained by interpreting aerial photographs, field surveys and integrated DTM data (Shiba 1992, Chung \& Sessions 2001, Ghaffarian \& Sobhani 2007, Kooshki et al. 2012).

The problem of accessing a forest through a network of secondary forest traffic infrastructure is particularly important for thinning, and for those mature stands where selective harvesting is performed. Even though machinery can move freely over the entire area in a uniform clear-cut, it is always recommended fixed trails to be used.

Almost all the negative effects of the use of machines in the forest reflect on trails (Moskalik \& Sadowski 2000), mainly soil compaction and damages to residual trees after forest operations. Skidders, tractors, and other heavy machinery used in forest practices may compact soils remarkably, depending on the type of equipment used, soil characteristics, etc. Compaction can take many years to recover, depending on the level of damage and many other environmental conditions. Limiting the area where compaction occurs by reducing machine drives to appropriately designed skid trails is one of best way to alleviate such problem (Schnepf 2008). Skid trail planning before felling operations can also reduce skidding damages. Machines moving only on trails cause damages which are located mostly near their working route (Naghdi et al. 2008, Tavankar et al. 2013).

In recent years, new opportunities have been developed to optimize roads and skid trails. This is mainly due to the use of information from the Airborne Laser Scanner (ALS) and Geographic Information System (GIS). Laser scanning provides precise data layers representing terrain surfaces in the form of Digital Terrain Models (DTM). DTM layers have attracted great interest to support forestry operations since they provide thorough and detailed information about terrain topography, which in turn is used to choose the best skidding system in complex forest areas (Mohtashami et al. 2012, Lubello 2008, Vega-Nieva et al. 2009). Krč \& Košir (2008) have also used Digital Elevation Models (DEM) to develop a model for terrain classification based on the best predicted skidding direction on a steep terrain. High resolution DTMs are also used to define various soil moisture indexes, providing information about the path to be taken by machines on a given terrain (Murphy et al. 2008).

Apart from DTM, ALS provides very precise and complex information about vegetation. Many different stand and tree charac- 
Tab. 1 - General characteristics of selected Scots pine stands (no. stands = 170).

\begin{tabular}{lccccc}
\hline Parameter & Minimum & Maximum & Sum & Mean & $\begin{array}{c}\text { Standard } \\
\text { deviation }\end{array}$ \\
\hline Area (ha) & 0.38 & 24.91 & 481.33 & 2.38 & 3.11 \\
Height (m) & 5 & 28 & - & 21 & 4 \\
Age (years) & 21 & 80 & - & 52 & 17 \\
Stocking & 0.3 & 1 & - & 0.73 & 0.72 \\
Dbh (cm) & 5 & 38 & - & 23 & 6 \\
Volume & 0 & 526 & - & 231 & 93 \\
$\left(\mathrm{~m}^{3} / \mathrm{ha}\right)$ & & & & & \\
\hline
\end{tabular}

teristics can be determined with the use of ALS point cloud or Canopy Height Model (CHM), such as height, structure, biomass volume, growth and density (Nilsson 1996, Popescu et al. 2003, Sterenczak \& Miscicki 2012, Sterenczak \& Mielcarek 2014). Once acquired ALS data can be utilized not just in forest inventory or monitoring, but also in many other management activities, such as optimization of the forest skid trail network.

The purpose of this paper is to present an analytical procedure that allows the optima determination of skid trails by using data from the Airborne Laser Scanner and digital forest maps. Single tree segmentation results in such decision support designing system are involved for the first time. Specific aims of the paper can be defined as follows:

- creation of a procedure for forest skid trail network optimization, fully based on GIS and ALS data;

- evaluation of pre- and post-procedure results on network length and the biomass volume planned to be cut; implementation of the method.

\section{Material and Methods}

\section{Study site}

The study site was a 1000 ha forest area owned by the Warsaw University of Life Sciences - SGGW, located at the experimental station in Gluchów, central Poland $\left(51^{\circ}\right.$ $45^{\prime} 19^{\prime \prime} \mathrm{N}, 20^{\circ} 06^{\prime} 30^{\prime \prime} \mathrm{E}$ ). Different forest types exist in the area, ranging from singlelayer stands of Scots pine (Pinus silvestris L.) and Common oak (Quercus robur L.) to multilayer, mixed stands of Birch (Betula pendula Roth), Alder (Alnus glutinosa L.), European beech (Fagus sylvatica L.) and Hornbeam (Carpinus betulus L.). Stand age varied between 30 and 120 years. The study area has a generally flat relief, with a mean elevation of about $185 \mathrm{~m}$ a.s.l. In order to verify the theoretical model presented here-
- analysis of the results with respect to the
Fig. 1 - Flow chart of the optimization algorithm.



inafter, Scots pine stands with different tree stocking and dimensions were studied, and skid trail network was optimized for each stand selected.

The model presented below was tested over 170 stands, where Scots pine was the dominant species (cover $>70 \%$ ). The main characteristics of the studied stands are reported in Tab. 1.

\section{Airborne Laser Scanning - data and processing}

The Falcon II airborne laser scanner system from Topographische Systemdaten $\mathrm{GmbH}$ (TopoSys, Biberach, Germany) was used for LIDAR small footprint data acquisition. The TopoSys System is based on two separate glass fiber arrays of 127 fibers each. Its specific design produces a push-broom measurement pattern of the ground. Details about the flight mission were described by Sterenczak \& Kozak (2011).

Based on data obtained, a 1-m digital terrain model was generated by the TREes VIS ${ }^{R}$ software (FELIS, Germany). For more details about software description and the algorithms implemented therein, see Weinacker et al. (2004).

\section{Optimization procedure}

The model represented in Fig. 1 simulates the most common harvesting methods used nowadays in Poland: (i) the traditional method, based on timber felling by chainsaws and extraction by skidders (TR); (ii) the fully mechanized method, using harvesters and forwarders (FM). The selected algorithm takes into consideration three types of inputs: Canopy Height Model (CHM), Digital Terrain Model (DTM) and layers from Forest Digital Maps (road network and forest compartments). The main steps for the implementation of the optimization algorithm are described in following paragraphs.

(1) A single-tree segmentation was carried out based on the CHM from Airborne Laser Scanning (ALS) data (Miscicki \& Sterenczak 2013). Segments representing single trees (polygon layer) were used in the next step as a point layer (Fig. 2). Each tree is represented by the centroid of a polygon.

(2) The Digital Terrain Model was first processed. The slope layer was generated using the Spatial Analyst ${ }^{\mathbb{B}}$ extension of the ArC GIS $^{\circledR} 10.1$ package (ESRI, Redwoods, CA, USA). To take into account the limits of traditional skidding by using skidders or agricultural tractors (maximum slope $<18 \%$ ) and forwarders (maximum slope $<40 \%$ ), slope was reclassified using the following classes: (class 1) 0-18\%; (class 2) 18-40\%; (class 3 ) slope $>40 \%$. According to Antonczyk (1995), the maximal slope limits for skidders are 33\% uphill and 50\% downhill, while is $18 \%$ (uphill and downhill) for agricultural tractors not equipped with Front 
Wheel Drive (FWD). In Poland, agricultural tractors without FWD are mostly used for thinning operations. For that reason, in the case of the traditional timber harvesting method, we assumed the maximum slope limit as $18 \%$. In other cases or countries, when tractors are equipped with FWD, the maximum limit is higher, especially in downhill direction. Areas smaller than $10 \mathrm{~m}^{2}$ with steep slopes were omitted from the analysis, being either local errors in the DTM or not important from a technological point of view. These data were used later for skid trail optimization.

(3) Forest Digital Maps were used to select the stands to be harvested and the roads to be used for timber transportation. Selected stands were 21 to 80 years old (Fig. 3). Based on the selected roads and compartments (forest units), a skid trail network was then created. If a forest road was already present, the longest side of the compartment was always used as the basis for planning skid trails. In cases of irregular-shaped forest units, trails were plotted in such a way to optimize the access (for example, along the longest axis of the unit), thus minimizing the sum of their lengths. Theoretical skid trails were designed with orthogonal direction to the base road and spacing of $40 \mathrm{~m}$ (traditional logging) or $20 \mathrm{~m}$ (fully mechanized logging).

(4) Optimization involved two main steps: the first was concerning the DTM slope limitation and the second was related to the minimal number of trees to be cut for the establishment of skid trails. The accessible area was determined for each harvesting system using the slope limits listed above. If the planned route of the skidding track crossed a pixel of the DTM too steep for the system considered (traditional or fully mechanized), a vertex was added to the modeled trail and a curve was created. The angle of the curve increased at each iteration by 1 degree until it was limited by the length of the logged tree. The iteration was terminated and the trail outlining was stopped when the radius of the curve falls below the following threshold (eqn. 1):

$$
R=\frac{L^{2}}{5 D}
$$

where $R$ is the minimum radius of the curve (m), $L$ is the length of felled timber (m), $D$ is the width of the skid trail (m). However, to reach inaccessible areas, such trail was extended to connect to the nearest adjacent trail leading to the road. The result of this step is the design of trails optimized in terms of the accessible slopes present in the area.

(5) The next step was aimed at minimizing the number of trees to be felled by taking advantage of the existing gaps in the forest stand. The input layer consists of the network of trails previously optimized by slope.

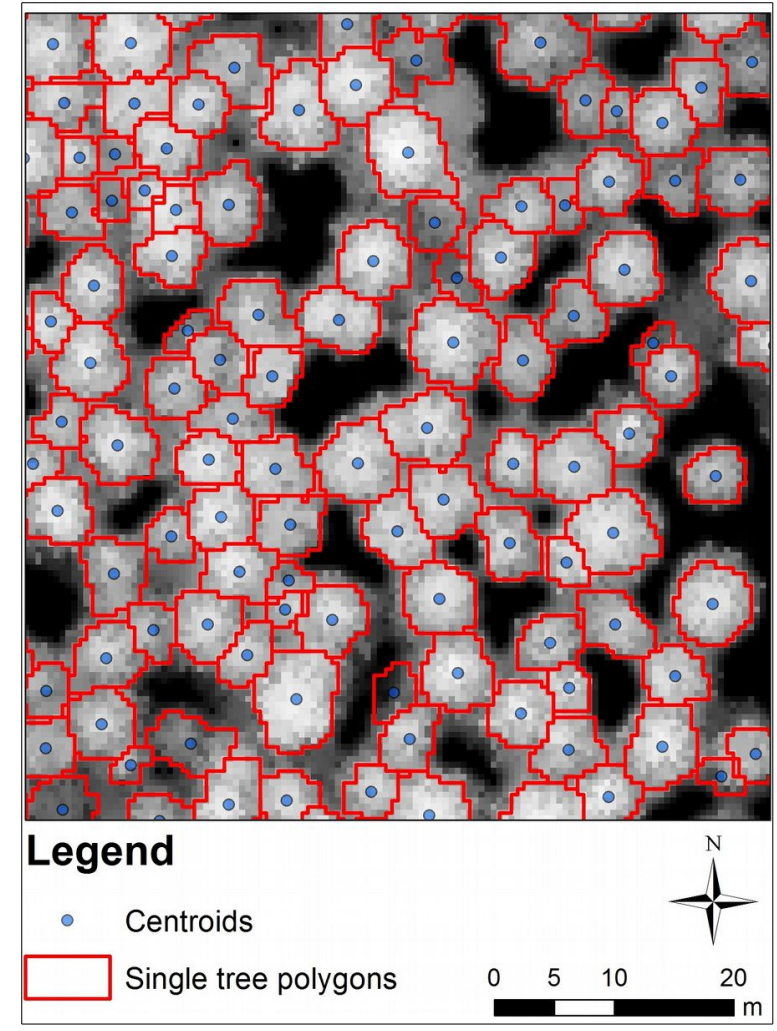

Fig. 2 - Single tree segmentation results.
One by one, each trail was optimized by shifting two vertices along its length in the range of \pm 2 times the width of the trail from its original axis. The largest gaps among all the available gaps allowing for a shift of a vertex (1 vertex per iteration) was identified within a buffer area (of size equal to four times the trail width) surrounding the skid trail considered. Using the above procedure,

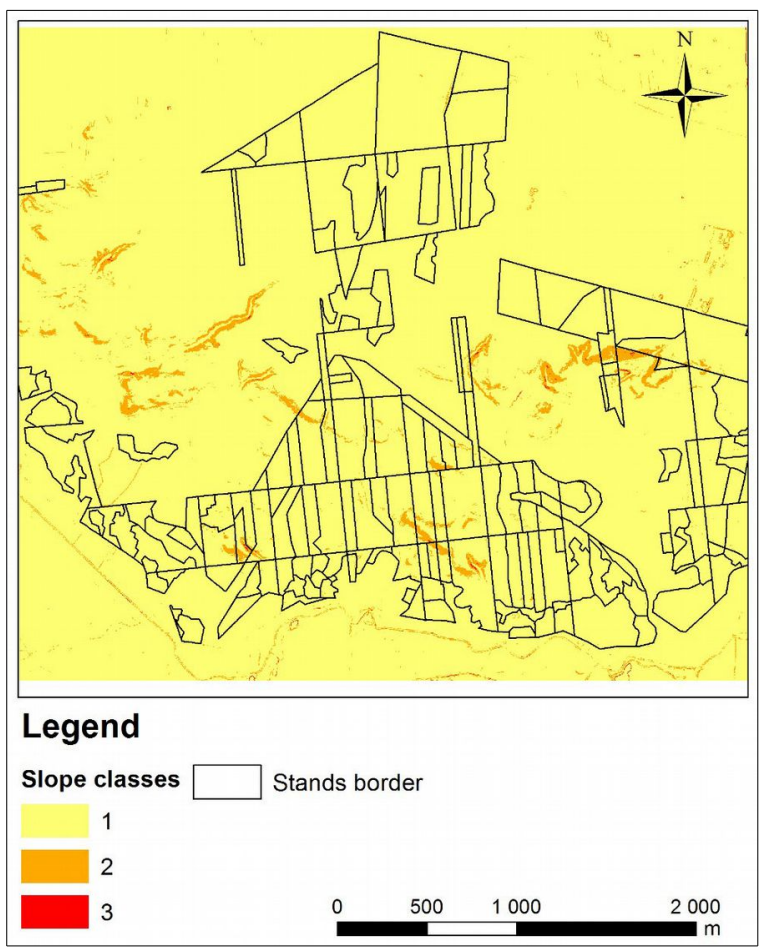

the best trail that minimize the number of trees to be felled was delineated. In the case of multiple trails with a tied number of trees to be felled, the shortest route was selected.

Such optimization process results in a new network of modeled skid trails that takes into account the type of the terrain and the distribution of trees in the forest stand.

Comparisons of the trail lengths and num-

Fig. 3 - Selected stands and slope classes. 




Fig. 4 - Average skid trail length $\left(\mathrm{m} \mathrm{ha}^{-1}\right)$ in the study area before and after optimization. (TRBO_L): Traditional logging method before optimization; (TRAO_L): traditional logging method after optimization; (FMBO_L): fully-mechanized logging method before optimization; (FMAO_L): fully-mechanized logging method after optimization.

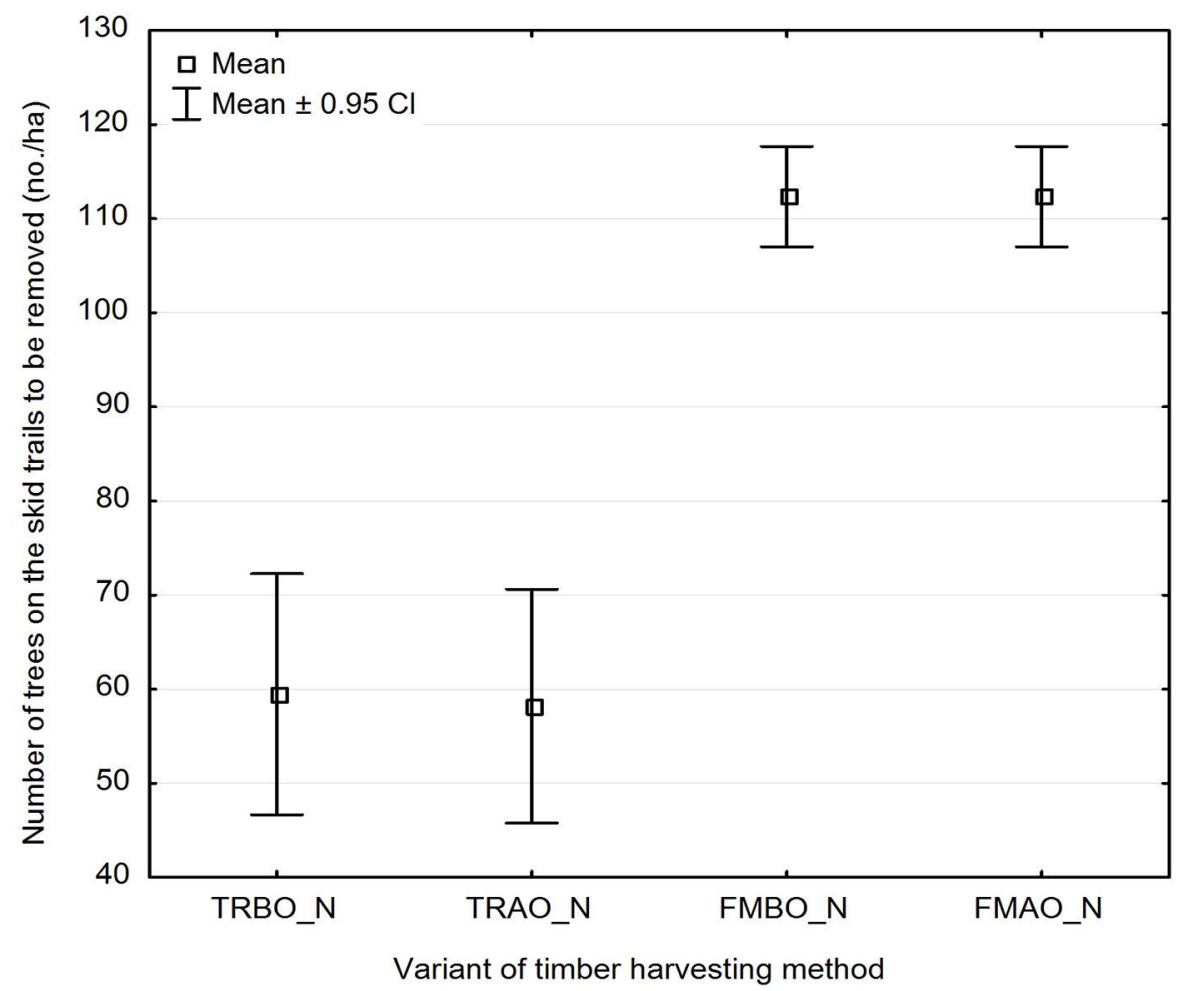

Fig. 5 - Number of trees to be removed before and after the optimization process. (TRBO N): Traditional logging method before optimization; (TRAO N): traditional logging method after optimization; (FMBO N): fully-mechanized logging method before optimization; (FMAO_N): fully-mechanized logging method after optimization. ber of trees to be felled located on the routes of modeled trails were carried out before and after model optimization. Differences between network variants were tested by Student's $t$-test using the statistical package Statistica $^{\circledR} 10.0$ (StatSoft, Tulsa, OK, USA).

Based on the number of trees to be removed to construct the trails, estimates of the total tree stem volume and the volume of the aboveground tree biomass were obtained. To this purpose, simple equations were used (Hempel 1968) based only on tree height as obtained from individual tree measurements by the ALS data (eqn. 2, eqn. 3):

$$
\begin{gathered}
V=a_{1} \cdot H^{b_{1}} \\
B A=a_{2} \cdot H^{b_{2}}
\end{gathered}
$$

where $H$ is the tree height (based on ALS single tree measurements, $\mathrm{m}$ ), $V$ is the single tree volume $\left(\mathrm{m}^{3}\right), B A$ is the aboveground biomass $(\mathrm{kg})$ of a single tree, $a_{1}$ is 0.000074 , $a_{2}$ is $0.0023, b_{1}$ is $3.1, b_{2}$ is 4.1398 .

\section{Results}

Based on the procedure described above, skid trails were traced and the trail network expanded to its maximum possible extent by taking advantage of the existing gaps in the study site.

Total length of skid trails for the traditional harvesting method was $109.17 \mathrm{~km}$ before optimization (TRBO_L), whereas it decreased by $2.14 \mathrm{~km} \mathrm{(2 \% )} \mathrm{to} 107.03 \mathrm{~km}$ after optimization (TRAO_L). For fully mechanized harvesting, the skid trail network was remarkably denser and longer, with an original length of $227.27 \mathrm{~km}$ (FMBO_L) that was reduced by $142 \mathrm{~m}(0.06 \%)$ to $227.13 \mathrm{~km}$ after optimization (FMAO_L).

A comparison of the average length of skid trails per ha before and after the optimization step is reported in Fig. 4 for the different harvesting methods considered. The large difference between trail lengths obtained for traditional and mechanized logging methods (over 60\%) was mainly due to the different distances between adjacent trails, which was initially set to 20 and $40 \mathrm{~m}$, respectively. Optimization by taking into account stand gaps did not significantly change the overall trail length. The observed difference in the average length of skid trails per ha using traditional methods was $2.01 \%$, while with fully mechanized methods was only $0.12 \%$. As shown in Tab. 2, such differences were not statistically significant.

Also, the single tree segmentation carried out allowed to determine the total number of trees to be felled for the construction of the skid trails in the study site. Before optimization, such figure was 16785 using the traditional harvesting method (TRBO N), whereas after optimization (TRAO N) it decreased by $465(2.8 \%)$ to 16320 . Using the fully 
Tab. 2 - Results of the Student's $t$-test for the comparison of the trail length per ha and the number of trees to be felled before and after the optimization process. Labels are the same reported in Fig. 4 and Fig. 5.

\begin{tabular}{|c|c|c|c|c|c|c|c|c|c|c|c|}
\hline Variable & Con & n 1 & Mean 2 & $t$ & df & $\mathbf{p}$ & N 1 and $N 2$ & SD 1 & SD 2 & F ratio & $\mathbf{p}$ \\
\hline \multirow{2}{*}{$\begin{array}{l}\text { Av. length of } \\
\text { skid trails ha }\end{array}$} & TRB & & & 9 & 338 & & 170 & 76 & & & \\
\hline & FMB & & & & 338 & & 170 & & & & 0.9669 \\
\hline \multirow{2}{*}{$\begin{array}{l}\text { N. trees to } \\
\text { be felled }\end{array}$} & TRBC & & 5 & 7 & 338 & 0 & 170 & 11 & 29 & 71 & 0.8127 \\
\hline & FMBO_N vs. FMAO_N & 113.22 & 112.35 & 0.2259 & 338 & 0.8213 & 170 & 31.88 & 35.23 & 1.0374 & 0.8115 \\
\hline
\end{tabular}

mechanized harvesting method, the number of trees was originally $55995(\mathrm{FMBO} N \mathrm{~N})$, while after optimization (FMAO L) this number was reduced by $308(0 . \overline{5} 5 \%)$ to 55687.

Fig. 5 shows the number of trees (per ha) standing on the surface of the designed skid trails in the study area. The trends obtained were similar to those observed for the trail length. However, differences between traditional and mechanized logging methods were higher, increasing to about $90 \%$. Also in this case, the optimization process adopted did not significantly reduce the number of trees to be felled. Differences in the numbers of trees before and after optimization were not statistically significant (Tab. 2), amounting to $2.57 \%$ and $0.77 \%$ for the traditional and the mechanized methods, respectively.

The volume of trees to be felled on the modeled skid trails decreased after optimization by $368 \mathrm{~m}^{3}$ (from 12363 to $11995 \mathrm{~m}^{3}$, $2.9 \%$ ) using the traditional harvesting method. For fully mechanized harvesting, this reduction was $214 \mathrm{~m}^{3}$ (from 41160 to $\left.40945 \mathrm{~m}^{3}, 0.5 \%\right)$. Similarly, the amount of aboveground biomass using the traditional harvesting method decreased after optimization from 9053 to 8782 tons $(2.9 \%)$, and from 30123 to 29971 tons $(0.5 \%)$ using the fully mechanized method.

\section{Discussion}

Accessing forest stands using an appropriately planned skid trail network allows not only logging and skidding operations to

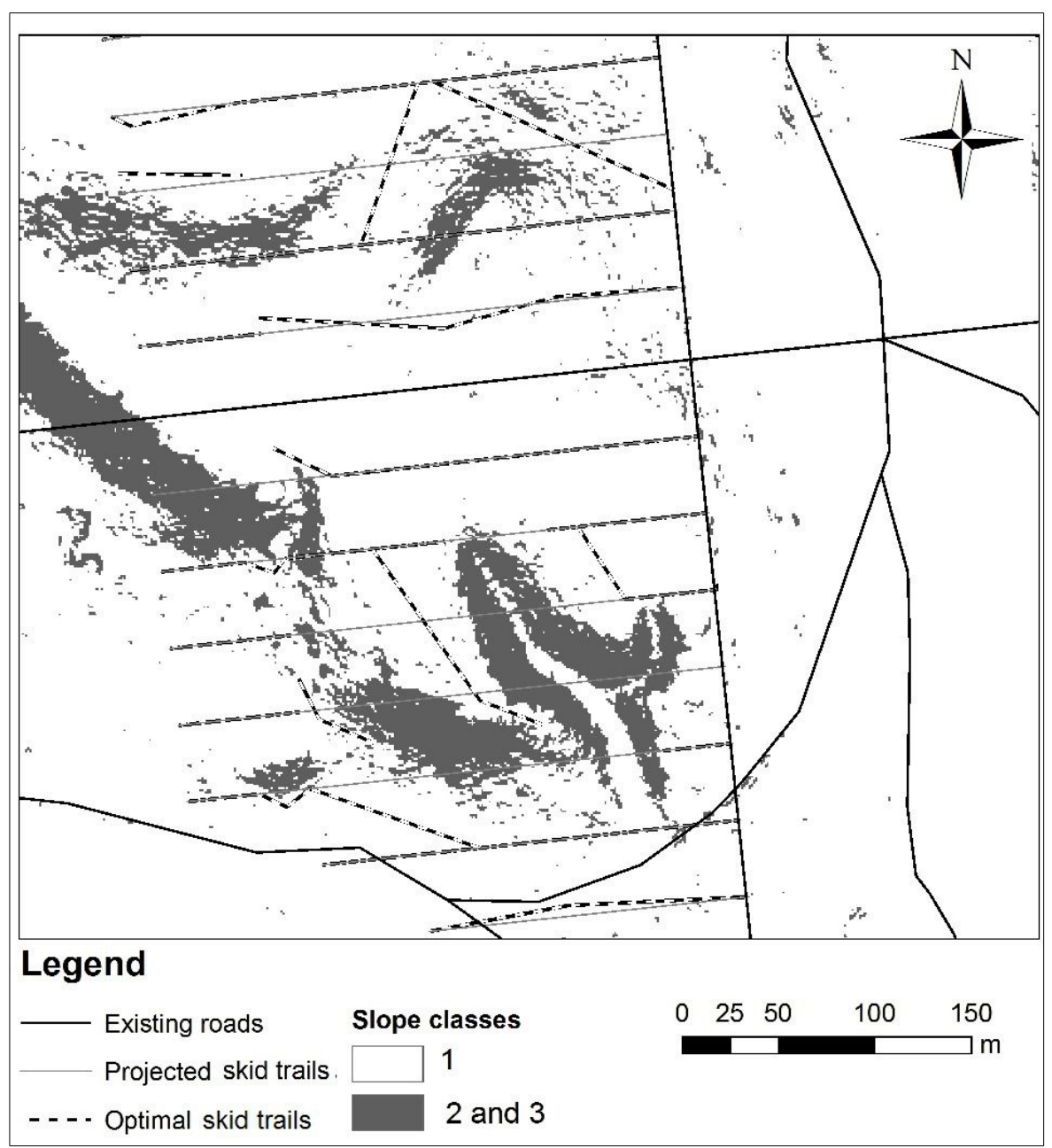

Fig. 6 - Skid trail network for the chosen forest area.

be carried out, but also other works related to silviculture and forest protection.

It is recommended to establish trails during the first thinning associated with logging operations. Trails should be designated along the shortest routes to extraction roads; however, schematic, rectilinear routes should be avoided, as well as the less accessible portions of the stand, such as wetlands, ponds, areas with steep slopes etc. Existing gaps, trails, etc., should be taken into account. An example of the skid trail network obtained after optimization on part of the study area is displayed in Fig. 6.

As reported by previous studies, harvest volume is an important factor to be considered in planning the forest transportation network, since a larger number of roads and higher skid trail densities are needed to reach those parts of the forest with higher annual growth and harvesting rates (König 1970, Sedlak 1983). In this paper, we estimated the harvest volume to be removed during thinning operation is about $35 \mathrm{~m}^{3} \mathrm{ha}^{-1}$. According to Zarzycki (1995), the area needed for skid trails covers about $10 \%$ of the total forest area using the traditional harvesting method, and $20 \%$ using fully-mechanized methods. This means that the wood volume which could be harvested during thinning operation reaches about 3.5 and $7 \mathrm{~m}^{3} \mathrm{ha}^{-1}$, respectively.

The optimization algorithm used in this study allowed the verification of a theoretical network of skid trails prior to their actual construction. Such procedure is time-saving and allows an early identification of areas inaccessible using different harvesting methods. The spatial analysis carried out using advanced GIS tools allowed alternative trail routes to be assessed, taking into account the type of terrain and the harvested wood to be extracted (Krč \& Košir 2008). An additional advantage of the proposed method stems from the use of segmentation aimed at distinguishing single trees in the crown layer, thus obtaining their spatial distribution on the ground. Such approach allowed to identify existing gaps or partial cutting plots to be included as preferential routes in developing the trail network.

The decrease in the overall trail length after optimization results from the avoidance of inaccessible steep areas that need to be circumvented by the modeled trails. However, as elevation increases, trail lengths also in- 
crease, mainly if inaccessible sites are small and linear-shaped, thus requiring the construction of longer routes.

Out results showed large differences between the traditional and machine-harvesting methods in the length of planned trails, and therefore in the number of trees to be felled for trail construction. Such differences are primarily due to the different distance between trails chosen as starting parameters for the two methods. In mountainous conditions, with greater restrictions due to steeper slopes, where trails are laid unevenly, somewhat different dependencies should be expected.

The trail optimization process using the existing stand gaps in the stand allowed to achieve better results, though the observed differences with the non-optimized network were relatively small. This could be interpreted as due to the high stocking rate (average of 0.73 ) and the fairly high stand densities in the study area. Indeed, starting plant density in Polish pine stands are often higher than in any other country (about 8000 ha $^{-1}$ ) As the stands develop, a reduction in density takes place by natural thinning or silvicultural practices; however, the gap size still remains quite small.

The algorithm used in our model was designed based on the criteria of minimizing the number of trees to be felled in the construction of the trail network. Of course, different criteria can be adopted, such as the avoidance of natural renewal areas, wetlands, particularly valuable plots in the stand, etc. In general, it is expected that the inclusion of more criteria in the model might enhance its utility, in terms of optimization of the skid trail network at the planning step.

The present paper aimed at demonstrating an alternative use of remote sensing data already available. Although collecting ALS data is quite expensive, their use for planning purposes may be prolonged for several years in sites where no management activities have been carried out.

\section{Conclusions}

The application of laser scanning technology and the use forest digital maps, along with the development of adequate algorithms, may allow the optimization of skid trail networks, as well as the reduction of number of trees to be felled in the network construction. Both the length of skid trails and the number of trees to be felled are mainly affected by the distance required between trails. This in turn depends on the logging and wood extraction technology to be used.

The use of existing stand gaps for trail delineation may contribute to the reduction of the number of trees to be felled in the construction of the skid trail network. However, our results did not show significant diffe- rences between the modeled network variants before and after the optimization procedure applied.

\section{Acknowledgements}

We are grateful to Krzysztof Bedkowski (Warsaw Universities of Life Sciences, Poland) for the permission of using ALS data obtained within the project of the Polish Ministry of Science and Higher Education: "Using airborne and terrestrial LIDAR scanning for analyzing forest spatial structure and forest function in landscape" (project no. 2 P06L 02229).

\section{References}

Antonczyk SZ (1995). Physiographic factors and their impact on a timber extraction. In: "Proecological and productive functions of skid trails in the modern forest management". Foundation "Development of SGGW", Warsaw, Poland, pp. 7-13. [in Polish]

Chung W, Sessions J (2001). Transportation planning under multiple objectives. In: Proceedings of the "International Mountain Logging and $11^{\text {th }}$ Northwest Skyline Symposium". Seattle (WA, USA) 10-12 Dec 2001, pp. 194-200. [online] URL: http://depts.washington.edu/sky2001/

Ghaffarian MR, Sobhani H (2007). Optimization of an existing forest road network using Network 2000. Croatian Journal of Forest Engineering 28 (2): 185-193. [online] URL: http://hrcak.srce.hr/ 18253?lang=en

Heinimann HR (1997). A computer model to differentiate skidder and cable-yarder based road network concepts on steep slopes. Journal of Forest Research 3 (1): 1-9. - doi: 10.1007/BF0276 0286

Hempel G (1968). Allometrische studie an Pinus cembra spp. sibirica (Rupr.) Kryl. und Abies sibirica (Ledeb.) [Allometric study of Pinus cembra spp. sibirica (Rupr.) Kryl. and Abies sibirica (Ledeb.)]. Archiv für Forstwesen 17 (11): 1099-1115. [in German]

Jourgholami M, Abdi E, Chung W (2013). Decision making in forest road planning considering both skidding and road costs: a case study in the Hyrcanian Forest in Iran. iForest 6: 59-64. - doi: 10.3832/ifor0640-006

Kobayashi H (1984). Planning system for road route locations in mountainous forests. Journal of the Japanese Forestry Society 66 (8): 313-319. Kooshki M, Hayati E, Rafatnia N, Ahmadi MT (2012). Using GIS to evaluate and design skid trails for forest products. Taiwan Journal of Forest Science 27 (1): 117-24. [online] URL: http:// www.researchgate.net/publication/237074243/

König W (1970). The influence of optimum roadspacing on opening up the state forest of NorthRhein Westphalia. University Regensburg, Germany, pp. 21-31. [in German]

Krč J, Košir B (2008). Predicting wood skidding direction on steep terrain by DEM and forest road network extension. Croatian Journal of Forest Engineering 29 (2): 177-188. [online] URL: http://hrcak.srce.hr/32193?lang=en
Leckie D, Gougeon F, Hill D, Quinn R, Armstrong L, Shreenan R (2003). Combined highdensity lidar and multispectral imagery for individual tree crown analysis. Canadian Journal of Remote Sensing 5: 633-649. - doi: 10.5589/m03024

Lubello D (2008). A rule-based SDSS for integrated forest harvesting planning. $\mathrm{PhD}$ thesis, Università degli Studi di Padova, Italy, pp. 213. Matthews DM (1942). Cost control in the logging industry. Mc Graw-Hill, New York ,USA, pp. 374. [online] URL: http://www.cabdirect.org/abstracts/19420617206.html

Miscicki S, Sterenczak K (2013). A two-phase inventory method for calculating standing volume and tree-density of forest stands in central Poland based on airborne laser-scanning data Forest Research Papers 74 (2): 127-136. - doi: 10.2478/frp-2013-0013

Mohtashami S, Bergkvist I, Löfgren B, Berg S (2012). A GIS approach to analyzing off-road transportation: a case study in Sweden. Croatian Journal of Forest Engineering 33 (2): 275-284. [online] URL: http://hrcak.srce.hr/116845?lang= en

Moskalik T, Sadowski J (2000). Forest accessibility for the fully mechanized timber harvesting. In: Proceedings of the "Communication infrastructure in multifunctional sustainable forestry". Rogow (Poland) 14 Dec 2000. Warsaw University of Life Sciences, Warsaw, Poland, pp. 8188. [in Polish]

Murphy PN, Ogilvie J, Meng FR, Arp P (2008). Stream network modeling using lidar and photogrammetric digital elevation models: a comparison and field verification. Hydrological Processes 22 (12): 1747-1754. - doi: 10.1002/hyp.6770 Naghdi R, Rafatnia N, Bagheri I, Hemati V (2008). Evaluation of residual damage in felling gaps and extraction routes in single selection method (Siyakhal forest). Iranian Journal of Forest and Poplar Research 16: 87-98.

Nevečerel H, Pentek T, Pičman D, Stankič I (2007). Traffic load of forest roads as a criterion for their categorization - GIS analysis. Croatian Journal of Forest Engineering 28 (1): 27-38. [online] URL: http://hrcak.srce.hr/11551?lang=en Newnham RM (1995). ROADPLAN: a tool for designing forest road networks. Journal of Forest Engineering 6 (2): 17-26. - doi: 10.1080/084352 43.1995.10702668

Nilsson M (1996). Estimating tree heights and stand volume. Remote Sensing of Environment 56: 1-7. - doi: 10.1016/0034-4257(95)00224-3 Pentek T, Nevečerel H, Poršinsky T, Pičman D, Lepoglavec K, Potočnik I (2008). Methodology for development of secondary forest traffic infrastructure cadastre. Croatian Journal of Forest Engineering 9 (1): 75-83. [online] URL: http:// hrcak.srce.hr/25730?lang=en

Popescu SC, Wynne RH, Nelson RF (2003). Measuring individual tree crown diameter with lidar and assessing its influence on estimating forest volume and biomass. Canadian Journal of Remote Sensing 29: 564-577. - doi: 10.5589/m03027 
Schnepf CH (2008). Prevent forest soil compaction - designate skid trails. UI Extension Forestry Information Series, Forest Management No. 8 University of Idaho, Moscow, ID, USA, pp. 1. [online] URL: http://idahodocs.cdmhost.com/ $\mathrm{cdm} /$ singleitem/collection/p15100coll7/id/17463 $/ \mathrm{rec} / 2$

Sedlak O (1983). General principles of planning forest road nets. Food and Agriculture Organization publication, FAO, Rome, Italy, vol. 14, pp. 17-36.

Shiba M (1992). Optimization of road layout in opening up of forests. In: Proceedings of the "Computer Supported Planning of Roads and Harvesting Workshop". Feldafing (Germany) 2628 Aug 1992, pp. 1-12.

Sterenczak K, Kozak J (2011). Evaluation of digital terrain models generated in forest conditions from airborne laser scanning data acquired in two seasons. Scandinavian Journal of Forest Research 26 (4): 374-384. - doi: 10.1080/028275 81.2011 .570781
Sterenczak K, Miscicki S (2012). Crown delineation influence on standing volume calculations in protected area. ISPRS - International Archives of the Photogrammetry, Remote Sensing and Spatial Information Sciences, vol. XXXIXB8, pp. 441-445. [online] URL: http://www.intarch-photogramm-remote-sens-spatial-inf-sci.net Sterenczak K, Mielcarek M (2014). Assessing one year pine growth at stand level with single tree detection based on ALS data. In: Proceedings of the " 6 th Precision Forestry Symposium: The anchor of your value chain" (Ackerman P, Gleasure E, Ham H eds). Stellenbosch University (Stellenbosch, South Africa) 3-5 March 2014, pp. 16-18. [online] URL: http://academic.sun.ac.za/forestry/ PF2014/

Tavankar F, Majnounian B, Bonyad AE (2013). Felling and skidding damage to residual trees following selection cutting in Caspian forests of Iran. Journal of Forest Sciences 59 (5): 196-203. [online] URL: http://www.agriculturejournals.cz/ publicFiles/93195.pdf
Weinacker H, Koch B, Heyder U, Weinacker R (2004). Development of filtering, segmentation and modeling modules for LIDAR and multispectral data as a fundament of an automatic forest inventory system. In: Proceedings of the "ISPRS Working Group on Laser-Scanners for Forest and Landscape Assessment" (Thies M, Koch $\mathrm{B}$, Spiecker $\mathrm{H}$, Weinacker $\mathrm{H}$ eds). Institute for Forest Growth, Institute for Remote Sensing and Landscape Information Systems, Freiburg, Germany, pp. 50-55. [online] URL: http://www.isprs.org/proceedings/XXXVI/8-W2/

Vega-Nieva DJ, Murphy PN, Castonguay $\mathrm{M}$, Ogilvie J, Arp PA (2009). A modular terrain model for daily variations in machine-specific forest soil trafficability. Canadian Journal of Soil Science 89 (1): 93-109. - doi: 10.4141/CJSS06033

Zarzycki S (1995). Principles of skid trails and landings design. In: "Proecological and productive functions of skid trails in the modern forest management". Foundation "Development of SGGW”, Warsaw, Poland, pp. 86-97. [in Polish] 